DOI: $\underline{10.35619 / \text { iiu.v2i13.366 }}$

Свищ Лілія

старший викладач кафедри української та іноземних мов Львівського державного університету фізичної культури

імені Івана Боберського, м. Львів, Україна

ORCID: 0000-0002-4360-9700 e-mail: lilyasvysch@ukr.net

\title{
ЦІННІСНА СКЛАДОВА СУЧАСНОЇ ПРОФЕСІЙНОЇ ПІДГОТОВКИ МАЙБУТНІХ ФАХІВЦІВ 3 ІНОЗЕМНОЇ ФІЛОЛОГІї
}

Анотація. У статті здійснено аналіз ціннісної складової сучасної професійної підготовки майбутніх фахівців з іноземної філології.

Необхідність ціннісної підготовки фахівців відповідної спеціальності визначена низкою спеціальних міжнародних документів, а також детермінована на національному рівні певними нормативними актами й теоретичними розробками. Обстоюється позиція, що за умов зміни аксіологічних орієнтирів, що $є$ характерним цивілізаційним трендом, нового значення набуває ціннісна освіта як головний засіб формування ціннісно-смислової сфери особистості. 3'ясовано, що в останні десятиліття на міжнародному рівні здійснюються вагомі зусилля, спрямовані на просування ідей ціннісної освіти, морально-етичного й ціннісного виховання.

У роботі розкрито сучасні підходи до ціннісної освіти філологів в аксіологічному й педагогічному контекстах. У статті представлено позиції щодо ціннісної освіти філологів українських та європейських дослідників. Встановлено, що на думку багатьох дослідників одним 3 важливих результатів сучасної вищої педагогічної освіти виступає аксіологічна компетентність студента, яка для педагогічних спеціальностей має фундаментальне значення. Сформульовано актуальні вимоги щодо змісту ціннісної складової сучасної професійної підготовки майбутніх фахівців 3 іноземної філології.

Ключові слова: професійна освіта, аксіологія, аксіологічні компетентності, ціннісна освіта, фахівці з іноземної філології.

Постановка проблеми. Розвинена й сформована ціннісно-смислова сфера особистості $\epsilon$ належним підгрунтям для засвоєння духовної культури суспільства, а упровадження аксіологічних підходів в освітній процес - запорукою перетворення культурних цінностей в стимули i мотиви практичної поведінки майбутніх фахівців. Саме тому сучасна професійна підготовка майбутнього педагога (зокрема, вчителя іноземних мов) вимагає звернення до аксіологічного дискурсу. Це тим більше 


\section{Інноватика у вихованні. Випуск 13.Том 2. 2021.}

актуально у часи глобальних змін початку XXI століття, які переживає людство i наслідком яких $є$ зміна аксіологічних орієнтирів, перегляд цінностей та їх ієрархій. Вказане зумовлює необхідність звернення до ціннісної складової професійної підготовки майбутніх фахівців з іноземної філології в умовах зміни аксіологічних орієнтирів.

Аналіз останніх досліджень 3 проблеми. Спеціальні дослідження, що проводяться 3 метою оцінки якісних змін у світі та в Україні, аргументовано доводять принциповий вплив на ціннісну сферу наслідків глобалізації початку XXI століття (зокрема, глобальна комунікація, міграція, міжнародні зв'язки) (Світове дослідження цінностей 2020 в Україні, 2020, с. 7). Внаслідок цього ефективні трансформації значно посилюють свій вплив як на окремо взяту людину, так і на суспільство загалом. На цьому тлі великої ваги набувають питання, з одного боку, збереження людиною самої себе, а 3 іншого - питання моральних та духовних якостей сучасної людини, змісту іï ціннісно-смислової сфери. Відповіді на ці виклики перебувають у площині цінностей освіти.

Зокрема, американський науковець Р. Шуерман, оцінивши стан сучасної освіти й виховання на основі широкого вивчення досвіду кращих шкіл в промислово розвинених країнах, дійшов висновку, що максимальна ефективність освітнього процесу досягається у тих навчальних закладах, де педагоги наголошують на засвоєнні найважливіших життєвих цінностей (Кирьякова, 2010). При цьому, як слушно наголошує українська дослідниця М. Раковська, сама освіта здатна виступати каталізатором культурних процесів, адже педагогічна діяльність - це насамперед діалог між культурами, обмін культурними цінностями, а вчитель повинен бути носієм передової культури (Раковська, 2015, с. 179). Результат такого діалогу, за словами британського дослідника Саймона Ліго-Бейкера - це внутрішні ціннісні зміни й трансформації, навіть паралельна практика різних цінностей залежно від життєвої ситуації (Lygo-Baker, 2017, p. 80).

Тому закономірною є потреба у здійсненні аксіологічної підготовки майбутніх фахівців різних галузей, а особливо майбутніх вчителів іноземної мови. Втім, спеціальних комплексних досліджень 3 цієї проблеми немає, а наявні праці розкривають лише окремі аспекти змісту значущості складової сучасної професійної підготовки майбутніх фахівців з іноземної філології.

Мета статті - на основі аналізу педагогічних й аксіологічних праць українських та зарубіжних авторів сформулювати актуальні вимоги щодо змісту складової сучасної професійної підготовки майбутніх фахівців 3 іноземної філології. Задля досягнення означеної мети вважаємо за доцільне в межах нашого дослідження вирішити такі завдання: 1) 3'ясувати сучасні підходи до ціннісної освіти в аксіологічному й педагогічному контекстах; 2) сформулювати вимоги щодо змісту ціннісної складової сучасної професійної підготовки майбутніх фахівців з іноземної філології з урахуванням зарубіжного досвіду такої підготовки. 


\section{Інноватика у вихованні. Випуск 13.Том 2. 2021.}

Виклад основного матеріалу дослідження. Зміни аксіологічних орієнтирів, що є характерним цивілізаційним трендом (Semple, 2019), актуалізують належну реакцію з боку освітніх інститутів. Нового значення набуває ціннісна освіта як головний засіб формування ціннісно-смислової сфери особистості (Пелех, Кукла, 2019). Освітні програми професійної підготовки у вищій школі мають сприяти формуванню надійного базису, забезпечувати умови формування розвиненої ціннісно-смислової сфери особистості. Особливого значення нині набувають сучасні освітні технології, що здатні посилити трансформаційну силу вищої освіти, готуючи студентів до діяльності у світі, який постійно змінюється (Harrison, 2017). Тому означені дефініції набувають особливого значення в контексті професійної підготовки майбутніх вчителів іноземної філології.

Зауважимо, що нині підготовка майбутніх фахівців 3 іноземної філології першого бакалаврського рівня вищої освіти здійснюється за спеціальністю 014 «Середня освіта», спеціалізація 014.021 «Англійська мова і література» галузі знань 01 Освіта/Педагогіка та за спорідненою спеціальністю 035.043 «Філологія» галузі знань 03 «Гуманітарні науки». Змістовний аналіз зазначених галузей та спеціальностей, унормованих відповідним переліком, дає підстави стверджувати, що їх наповнення не створює сприятливих умов для забезпечення ціннісної складової професійної підготовки майбутніх фахівців з іноземної філології, відсутні також механізми формування ціннісно-смислової сфери майбутнього вчителя, а також не передбачено методичного забезпечення для становлення аксіологічної свідомості шляхом перетворення соціальних цінностей в особисті, засвоєння соціально-значущих ціннісних орієнтацій й трансформацію їх в індивідуальні ціннісні орієнтації. Ці обставини $є$ вагомим спонукальним мотивом практичних пошуків шляхів модернізації національної освітньої діяльності у сфері професійної підготовки майбутніх фахівців з іноземної філології.

Відзначимо, що міжнародна група дослідників на чолі 3 британськими науковцями Т. Ловатом та Р. Тоомі у своїй праці «Ціннісна освіта і якісне навчання» (Lovat, Toomey, 2009) зазначала, що останнім часом на міжнародному рівні вчені та фахівці-практики докладають значних зусиль, спрямованих на просування ідей ціннісної освіти, морально-етичного й ціннісного виховання. Проте суспільство постійно стикається 3 військовими конфліктами, расизмом, тероризмом, бактеріологічними війнами, що грунтуються на антигуманних й екстремістських ідеях.

Український педагог i дослідник Ю. Пелех розглядає поняття «освіта» як багатогранне й полікомпонентне, як таке, що містить «високоінтелектуальні дослідницькі й інноваційні складники, що спрямовані, насамперед, на перетворення людини, поліпшення у процесі теоретико-практичної підготовки іiі поведінки і формування (розуміння й усвідомлення) повного спектра загальнолюдських цінностей в інтересах $\mathrm{i}$ iï самої, і всього суспільства» (Пелех, Кукла, 2019, с. 96). Враховуючи це, 


\section{Інноватика у вихованні. Випуск 13.Том 2. 2021.}

науковець наголошує, що реформи національної освіти повинні, серед іншого, передбачати зміну типу мислення, мотиваційної основи, а також забезпечувати готовність учителя до засвоєння, розуміння, розвитку i застосування знань, навичок і цінностей у повсякденному житті (Пелех, Кукла, 2019, с. 109-110).

Латвійський дослідник Є. Швітала вказує на ще одну причину забезпечення ціннісної складової професійної підготовки майбутніх педагогів, зокрема фахівців з іноземної філології, слушно наголошуючи на тому, що вчитель перебуває у перманентній складній ситуації, оскільки має справу 3 подекуди діаметрально протилежними поглядами й позиціями - з боку вчительського корпусу і учнів (вихованців), щодо змісту тих цінностей, які мають право залучатися до освітнього процесу. Школа й вчителі перебувають під дуже великим впливом двох потоків цінностей: один - це сім’ї учнів, а другий - універсальна теорія, представлена офіційними органами, що беруть участь у навчальному процесі. «У багатьох випадках існує надзвичайно різне ставлення до життя та моралі, але певний вид консенсусу повинен бути досягнутий у будьякій школі» (Świtała, p. 59). Практичним наслідком такої ситуації $\epsilon$ необхідність спеціальної аксіологічної підготовки майбутніх педагогів, яка забезпечила б їх компетентностями вирішувати аксіологічні конфлікти, вибудовувати обгрунтовані й соціально прийнятні корисні системи, дотримуючись принципів гуманізму й толерантності.

Своєю чергою, українська дослідниця і практик в освітній сфері Н. Шетеля вказує на те, що нині є особлива потреба у створенні нової моделі вищої освіти, здатної органічно поєднувати в собі завдання формування професіоналів 3 високим рівнем компетентностей на тлі забезпечення розвиненої ціннісної культури. «Це тим більше актуально, якщо взяти до уваги той факт, що на наших очах відбувається становлення нової креативної цивілізації, і в цих умовах освіта повинна готувати людину для життя у мінливій реальності, в тому числі до ситуації переосмислення цінностей й формування нових ціннісних орієнтацій» (Шетеля, 2020, с. 774).

Завдання сучасної ціннісної освіти корелюються також 3 нинішньою цивілізаційною ситуацією, що вирізняється гранично високим ступенем соціальної активності особистості. У зв'язку з цим, як відзначає Л. Баєва, сучасна аксіологія орієнтована на вирішення практичних завдань, пов'язаних з розв'язанням проблеми сенсу і цінності людства як суб'єкта. «Життя, свобода, духовність і терпимість - цінності, що виступають основами вдосконалення, як окремої особистості, так і суспільства в цілому» (Баева, 2003, с. 224). Концептуальною для нас є також позиція українського науковця А. Кузьмінського, відповідно до якої, цінності виступають «підгрунтям для осмислення, пізнання та конструювання цілісного образу соціального світу, для регуляції поведінки людини у всіх iï проявах під час ухвалення рішення в ситуації вибору» (Кузьминский, 2011, с. 48). Американський соціолог Т. Парсонс вказував, що суспільство 


\section{Інноватика у вихованні. Випуск 13.Том 2. 2021.}

саме для збереження своєї єдності й цілісності, забезпечення саморегуляції і консенсусу напрацьовує цінності як вищі принципи (ідеї): «суспільство як цілісна система, в наші дні організована у вигляді єдиного політичного колективу, і $є$ інституціолізуючою єдиною, більш-менш інтегрованою системою цінностей» (Парсонс, 1965, с. 30). Розвиваючи думку американського вченого, додамо, що утвердження цінностей, формування ціннісно-смислової сфери, аксіологічної свідомості та аксіологічної культури загалом сприяє орієнтації людини на потреби духовного, а не утилітарного порядку, надання пріоритету гуманістичним цінностям, а не егоїстичним антицінностям. До того ж саме гуманістичні (або вищі) цінності як універсальні містять у собі консолідуючий потенціал.

Отож, здійснене нами дослідження наочно доводить, що загальною позицією представників різних аксіологічних концепцій можна вважати положення, відповідно до якого: утвердження цінностей, формування ціннісно-смислової сфери та аксіологічної свідомості загалом сприяє орієнтації людини на потреби духовного, а не утилітарного порядку, надання пріоритету гуманістичним цінностям, a не егоїстичним антицінностям. 3 іншого боку, представники педагогічної науки загалом поділяють позицію, що одним 3 важливих результатів сучасної вищої професійної освіти (зокрема, педагогічної) виступає аксіологічна компетентність студента, яка для педагогічних спеціальностей має фундаментальне значення. Постає питання щодо практичного забезпечення ціннісної складової сучасної професійної підготовки майбутніх фахівців з іноземної філології.

Проведений нами контент-аналіз на предмет аксіологічного навантаження Стандарту вищої освіти України для першого (бакалаврського) рівня, галузь знань 03 Гуманітарні науки, спеціальність 035 «Філологія», уможливив виявлення його недоліків щодо формування аксіологічних компетентностей. У зв'язку з цим вважаємо за доцільне звернутися до досвіду у сфері професійної підготовки майбутніх фахівців з іноземної філології в Об’єднаному Королівстві Великобританії. Увага до британських філологічних програм зумовлена вагомим та грунтовними традиціями філологічної освіти, а також відомими теоретичними i практичними напрацюваннями у сфері ціннісної освіти.

Відзначимо, що в Об’єднаному Королівстві керуються вимогами Загальноєвропейської системи мовної компетенції (Common European Framework), яка регламентує розвиток у майбутнього фахівця відповідного профілю лінгвістичної бази 3 усіма можливими лінгвістичними компетенціями. Загальноєвропейська система мовної компетенції розглядається іiі авторами як важливий крок європейської спільноти до мовної освіти, спрямований на захист мовного та культурного розмаїття, сприяння багатомовній та міжкультурній освіті, утвердження права на якісну освіту для всіх та поглиблення міжкультурного діалогу, соціальної інтеграції i демократії. Це дає 


\section{Інноватика у вихованні. Випуск 13.Том 2. 2021.}

можливість робити висновок, що засоби мовної освіти європейці вважають тими фундаментальними цінностями, без яких немислимо уявити сучасне й успішне європейське інтеграційне об єднання Свропейський Союз.

На практиці підготовка вчителів-філологів у Великій Британії здійснюється за такими напрямами: вчитель англійської мови як рідної (лінгвістика) та як іноземної (TESOL); вчитель іноземних мов (класичних та сучасних) i, окрім того, культурознавчі студії (наприклад, американські, де вивчається американська культура і література) (Чорна, 2011, с. 6). Організація професійної підготовки майбутніх фахівців 3 іноземної філології відбувається з урахуванням Національного навчального плану 3 англійської мови, інновацій у педагогіці і психології та спрямована на розвиток у студентів мовленнєвих умінь (аудіювання, говоріння, читання та письма) (Козаченко, 2016, с. 381).

Особливе значення у процесі професійної підготовки майбутніх фахівців з іноземної філології відводиться аксіологічній складовій. Логіка полягає в тому, що вчитель відіграє ключову роль в організації освітнього процесу, але при цьому очевидним є той факт, що вчити і навчити без цінностей - неможливо. «Лише поборовши моральну складність й неоднозначність навчального процесу, ми можемо сподіватися виявити хороші та правильні речі, які слід робити за будь-якої сукупності обставин, тобто знати як правильно навчати» (Johnston, 2003, p. 21). Вчитель, будучи носієм власних цінностей й ціннісних установок, повинен пам'ятати, що він наділений владою і має бути відповідальним за формування суспільно значущих, гуманістичних цінностей (Hall, 2011, p. 15). Це, вочевидь, вимагає від самого вчителя глибоких аксіологічних знань й розвиненої аксіологічної свідомості.

Прикладом практичної реалізації аксіологічних підходів та ідей ціннісної освіти є, наприклад, мовні програми Школи історії, мов та культур Ліверпульського університету. Ціннісна складова тут забезпечується низкою дисциплін, що формують професійні компетентності майбутніх фахівців з іноземної філології, в тому числі й аксіологічні. Варто вказати на такі дисципліни, які вивчають майбутні знавці німецької філології: «Introduction to German Studies/ Вступ до германістики», «Texts and Context in German/ Тексти та контекст німецькою мовою», «German Cinema From the Expressionism to the Present /Німецьке кіно від експресіонізму до сьогодення», «The German Democratic Republic: Politics, Culture, Memory/ Німецька Демократична Республіка: політика, культура, пам'ять», «Propaganda and Censorship/ Пропаганда та цензура», «Language \& Society /Мова та суспільство», «Proficient German / Німецька мова високого рівня» (German BA (Hons). School of Histories, Languages and Cultures, 2020).

Своєю чергою Університет Ньюкасла пропонує, серед іншого, бакалаврську програму «Сучасні мови, переклад та усний переклад» («Modern Languages, Translation and Interpreting») (Modern Languages, 


\section{Інноватика у вихованні. Випуск 13.Том 2. 2021.}

Translation and Interpreting, 2020). Аналіз цієї програми також вказує на завдання професійної підготовки іноземних філологів щодо засвоєння історичних, народознавчих, культурно-побутових, соціально та професійно-значущих цінностей. Засвоєння цінностей знаннєвого змісту і цінностей, що визначають особистість педагога досягається за допомогою вивчення, зокрема, таких курсів (для майбутніх знавців французької філологіi): «Linguistic Variation in French/Мовна варіація у французькій мові», «Introduction to Cultural Studie/Вступ до культурології», «Translation Theory and Practice/ Теорія та практика перекладу», «Historical Perspectives on the French Language / Історичні перспективи французької мови», «Classic French Cinema / Класичне французьке кіно», «Paris: Aspects of History and Culture /Париж: аспекти історії та культури», «А Comparative History of German and English: phonology, morphology, syntax and lexicon / Порівняльна історія німецької та англійської мов: фонологія, морфологія, синтаксис та лексика».

Показово, що обидва наведених приклади програм професійної підготовки майбутніх фахівців з іноземної філології Ліверпульського університету й Університету Ньюкасла наочно підтверджують дотримання ïx укладачами принципів Загальноєвропейської системи мовної компетенції у контексті посилення міжкультурного діалогу, соціальної інтеграції та демократії, а також реалізують на практиці настанови теорії ціннісної освіти у мовній сфері. Британські освітні програми філологічної підготовки очевидно забезпечують формування аксіологічної компетентності як невід'ємної складової професійної готовності майбутніх фахівців з іноземної філології.

Зважаючи на проведений аналіз, вбачаємо за доцільне переглянути зміст аксіологічного навантаження Стандарту вищої освіти України для першого (бакалаврського) рівня, галузь знань 03 Гуманітарні науки, спеціальність 035 «Філологія». Досягти підвищення ефективності формування аксіологічної компетентності в національній освітній практиці вбачаємо можливим як за допомогою дисциплін соціогуманітарного циклу, так і предметів професійної (філологічної й педагогічної) підготовки. У соціо-гуманітарному циклі необхідно розшири можливості ціннісної підготовки шляхом інтеріоризації історичних, народознавчих, культурно-побутових, соціально та професійно-значущих цінностей власної держави та держави, мова та культура якої вивчається. Своєю чергою, щодо предметів професійної (філологічної й педагогічної) підготовки, то йдеться про необхідність поєднання філологічних наук 3 культурними, філософськими, психологічними та історичними рефлексіями.

Висновки i перспективи подальших розвідок. Актуальним завданням в сучасних умовах зміни аксіологічних орієнтирів $€$ професійна підготовка фахівців з іноземної філології як педагогів нової якості, які здатні відповідно до своїх професійних компетентностей (зокрема, ціннісних) усвідомлено й креативно підходити до проєктування 


\section{Інноватика у вихованні. Випуск 13.Том 2. 2021.}

освітнього процесу, створювати нові цінності й репродукувати традиційні й гуманістичні, які потім реалізуються у класі i сприймаються ( $\epsilon$ зрозумілими і прийнятними) школярами.

Проведене дослідження дає підстави для таких висновків.

1. Спільним для представників різних аксіологічних концепцій можна вважати положення про те, що формування ціннісно-смислової сфери та аксіологічної свідомості загалом сприяє орієнтації людини на потреби духовного, надання пріоритету гуманістичним цінностям. Своєю чергою представники педагогічної науки притримуються думки, що одним 3 важливих результатів сучасної вищої освіти (зокрема, педагогічної) постає аксіологічна компетентність студента, яка для педагогічних спеціальностей має фундаментальне значення. За умови реалізації таких підходів у процесі професійної підготовки, студенти-філологи розвивають гнучкість та оригінальність стосовно сприйняття й індивідуального вирішення гуманістичних питань, що у майбутньому забезпечить ефективність суспільної і професійної комунікації.

2. Роль ціннісного медіуму (посередника й мотиватора) майбутній учитель іноземної мови здатен виконувати лише за умови особистісного оволодіння, засвоєння й розуміння аксіологічних знань, що потребує залучення студента до ціннісного дискурсу, його особистої інтелектуальної роботи щодо осмислення ціннісної й морально-етичної проблематики паралельно із формуванням власної ціннісно-смислової сфери й ціннісної свідомості. Тому, практичним результатом професійної підготовки майбутніх фахівців з іноземної філології має стати формування аксіологічної компетентності. У цьому напрямі корисним $є$ досвід професійної підготовки майбутніх фахівців 3 іноземної філології в Об’єднаному Королівстві Великої Британії.

Перспективи подальших розвідок вбачаємо у здійсненні педагогічного моделювання процесу формування ціннісно-смислового досвіду студентів-філологів під час вивчення дисциплін соціогуманітарного циклу, а також предметів професійної (філологічної й педагогічної) підготовки.

\section{СПИСОК ВИКОРИСТАНИХ ДЖЕРЕЛ}

Світове дослідження цінностей 2020 в Україні. (2020). К.: Український центр європейської політики.

Кирьякова, А. (2010). Теория ценностей - методологический базис аксиологии образования. В: Аксиология и инноватика образования, URL: http://www.orenport.ru/axiology/docs/3/3.pdf. [Дата доступу 06.07.20].

Раковська, М. (2015). Концептуалізація філософського погляду на проблему формування аксіологічного потенціалу професійної підготовки. Вісник Чернігівського національного педагогічного університету. Серія: Педагогічні науки. 130. СС. 176-180. 


\section{Інноватика у вихованні. Випуск 13.Том 2. 2021.}

Lygo-Baker, S. (2017) The Role of Values in Higher Education. Pedagogic Frailty and Resilience in the University. Rotterdam : Brill-Sense, PP. 79-91.

Semple, R. (2019). Do Values Change Over Time? FlashPoint, October 03 URL: https://www.flashpointleadership.com/blog/do-values-change-over-time [Accessed 08.10.20].

Пелех, Ю. та Кукла, Д. (2019). Система цінностей майбутнього фахівця i його місце на сучасному ринку праці. Рівне: «Волинські обереги».

Harrison Dianne, F. (2017). The Role of Higher Education in the Changing World of Work. EDUCAUSE, October 23, URL: https://er.educause.edu/articles/2017/10/the-role-of-higher-education-in-thechanging-world-of-work. [Accessed 28.09.20].

Lovat, T., Toomey, R. (eds.). (2009). Values Education and Quality Teaching, Amsterdam: Springer Netherlands.

Świtała, E. (2013). Values Education ñ a Reality or Myth in Polish Schools. Discourse and Communication for Sustainable Education 4. PP. 5766.

Шетеля, Н. (2020). Ціннісна освіта: сучасний зміст. В: The 4th International scientific and practical conference "Science and education: problems, prospects and innovations" (December 29-31, 2020). CPN Publishing Group, Kyoto, Japan. PP. 773-778.

Баева, Л. (2003). Ценностные основания индивидуального бытия: Опыт экзистенциальной аксиологии. М.: Прометей.

Кузьминский, А. (2011). Ценностные ориентиры современного образования в М. И. Лукьяновой, Е. А. Лодатко (ред.) В: Ценности профессиональной деятельности современного педагога: межвузовский сборник научных трудов. Черк.-Ульян.: УИПКПРО. СС.47-55.

Парсонс, Т. (1965). Общетеоретические проблемы социологии в Мертон Р. К., Брум. Л., Котрелл Л. С. (ред.) Соииология сегодня: Проблемы и перспективы. М.: Прогресс. СС. 25-67.

Чорна, О. (2011). Особливості сучасної підготовки вчителів-філологів у Великій Британії. Науковий вісник Південноукраӥнського національного педагогічного університету ім. К. Д. Уиинського, № 5-6. СС. 3-10.

Козаченко, I. (2016). Підготовка вчителів іноземних мов у Великій Британії. Позитивний досвід для України. Молодий вчений. 4. СС. 379-383.

Johnston,B. (2003). Values in English Language Teaching. Mahwah, NJ: Lawrence Erlbaum Associates, Publishers.

Hall, G. (2011). Exploring values in English language teaching:teacher beliefs, reflection and practice. The Teacher Trainer. 24(2). PP. 13-15.

German, B. (Hons). School of Histories, Languages and Cultures. (2020). University of Liverpool. URL: https://www. liverpool.ac.uk/study/ undergraduate/courses/german-ba-hons/overview/ [Accessed 08.12.20]. 


\section{Інноватика у вихованні. Випуск 13.Том 2. 2021.}

Modern Languages, Translation and Interpreting. (2020). Faculty of Humanities and Social Sciences. Newcastle University/ URL: https: //www. ncl.ac.uk/undergraduate/degrees/r9q9/\#modules-learning [Accessed 08.12.20].

\section{REFERENCES}

Svitove doslidzhennia tsinnostei 2020 v Ukraini [World values survey 2020 in Ukraine]. (2020) K.: Ukrainskyi tsentr yevropeiskoi polityky [in Ukrainian].

Kyriakova, A. (2010). Teoryia tsennostei - metodologicheskiy bazis aksiologii obrazovaniya [The theory of values - the methodological basis of the axiology of education], Aksiologiya $i$ innovatika obrazovaniya. URL: http: //www.orenport.ru/axiology/docs/3/3.pdf. [Accessed 06.07.20]. [in Russian].

Rakovska, M. (2015). Kontseptualizatsiia filosofskoho pohliadu na problemu formuvannia aksiolohichnoho potentsialu profesiinoi pidhotovky [Conceptualization of the philosophical view on the problem of formation of axiological potential of professional training]. Visnyk Chernihivskoho natsionalnoho pedahohichnoho universytetu. Seriia : Pedahohichni nauky. 130. SS.176-180. [in Ukrainian].

Lygo-Baker, S. (2017). The Role of Values in Higher Education. Pedagogic Frailty and Resilience in the University. Rotterdam : Brill-Sense. PP. 79-91.

Semple, R. (2019). Do Values Change Over Time?' FlashPoint, October 03. URL: https://www.flashpointleadership.com/blog/do-values-change-overtime [Accessed: 08.10.20].

Pelekh, Yu. \& Kukla, D. (2019). Systema tsinnostei maibutnoho fakhivtsia i yoho mistse na suchasnomu rynku pratsi. [The value system of the future specialist and his place in the modern labor market]. Rivne: "Volynski oberehy". [in Ukrainian].

Harrison Dianne, F. (2017). The Role of Higher Education in the Changing World of Work. EDUCAUSE, October 23. URL: https: //er.educause.edu/articles/2017/10/the-role-of-higher-education-in-thechanging-world-of-work. [Accessed 28.09.20].

Lovat, T. \& Toomey, R. (eds.). (2009). Values Education and Quality Teaching, Amsterdam: Springer Netherlands.

Świtała, E. (2013). Values Education ñ a Reality or Myth in Polish Schools. Discourse and Communication for Sustainable Education 4. PP. 5766.

Baeva, L. (2003). Tsennostnye osnovaniya individualnogo bytiya: Opyt ekzystentsyalnoi aksiologii [Value foundations of individual being: an experience of existential axiology]. M.: Prometei. [in Russian].

Kuzminskiy, A. (2011). Tsennostnye orientiry sovremennogo obrazovaniya v M. Y. Lukianovoi, E. A. Lodatko (red.). [Value guidelines of modern education in M.I.Lukyanova, E.A.Lodatko]. Tsennosti professionalnoi deyatelnosti sovremennogo pedagoga: mezhvuzovskiy sbornik nauchnykh trudov. Cherkassy-Ulyanovsk: UYPKPRO. SS.47-55. [in Ukrainian]. 
Parsons, T. (1965). Obshcheteoreticheskiye problemy sotsyologii [General theoretical problems of sociology] v Merton R. K., Brum. L., Kotrell L. S. (red.) Sotsyologiya segodnya: Problemy i perspektivy. Moskva: Progress. ss. 25-67. [in Russian].

Chorna, O. (2011). Osoblyvosti suchasnoi pidhotovky vchyteliv-filolohiv u Velykii Brytanii [Features of modern training of teachers of philology in Great Britain]. V: Naukovyi visnyk Pivdennoukrainskoho natsionalnoho pedahohichnoho universytetu im. K. D. Ushynskoho, No 5-6. SS. 3-10. [in Ukrainian].

Kozachenko, I. (2016). Pidhotovka vchyteliv inozemnykh mov u Velykii Brytanii. Pozytyvnyi dosvid dlia Ukrainy [Training of foreign language teachers in Great Britain. Positive experience for Ukraine]. Molodyi vchenyi, No 4. SS. 379-383. [in Ukrainian].

Johnston, B. (2003). Values in English Language Teaching. Mahwah, NJ: Lawrence Erlbaum Associates, Publishers.

Hall, G. (2011). Exploring values in English language teaching:teacher beliefs, reflection and practice. The Teacher Trainer. 24(2). PP. 13-15.

German, B. (Hons). School of Histories, Languages and Cultures. (2020). University of Liverpool. URL: https: //www.liverpool.ac.uk/study/ undergraduate/courses/german-ba-hons/overview. [Accessed 08.12.20].

Modern Languages, Translation and Interpreting. (2020). Faculty of Humanities and Social Sciences. Newcastle University. URL: https: //www. ncl.ac.uk/undergraduate/degrees/r9q9/\#modules-learning [Accessed: 08.12.20].

\section{VALUE COMPONENT IN MODERN PROFESSIONAL TRAINING OF FUTURE FOREIGN LANGUAGE TEACHERS}

Lilia Svyshch

Senior Lecturer at the Department of Ukrainian and Foreign languages Ivan Boberskyi Lviv State University of Physical Culture, Lviv, Ukraine ORCID: 0000-0002-4360-9700 e-mail: lilyasvysch@ukr.net

\footnotetext{
Abstract. The article deals with the value component in modern professional training of future foreign language teachers.

The need for value training of specialists in the relevant specialty is defined by several international documents, as well as determined by certain regulations and theoretical developments at the national level. This is substantiated by the fact that under the conditions of axiological landmarks change, which is one if the characteristics of civilization trend, value education acquires new significance as the main means of forming the value and semantic sphere of personality. It is shown that during recent decades significant efforts have been made at the international level to promote the ideas of value education, moral, ethical and value upbringing.
} 


\section{Інноватика у вихованні. Випуск 13.Том 2. 2021.}

The paper reveals modern approaches to the value education of teachers in axiological and pedagogical contexts. Generally accepted position is that now there is a need for special axiological training of future foreign languages teachers, which would provide them with the ability to resolve axiological conflicts, to build sound and socially acceptable value systems, based on principles of humanism and tolerance.

The study reveals the arguments and opinions of the value education of foreign language teachers among Ukrainian and European researchers. It has been identified that according to many researchers one of the important results of modern higher pedagogical education is the axiological competence of the student, which is fundamental for pedagogical specialties. The actual requirements concerning the maintenance of a value component of modern professional training of future foreign language teachers have been formulated.

Keywords: professional education, axiology, axiological competencies, value education, foreign language teachers.

Стаття надійшла до редакиіï 30.04. 2021 р. 